\title{
A New Lignan Glycoside from the Roots of Silene tatarinowii Regel
}

\author{
Xiaofei Liang $\oplus^{\#}$, Yuze Li $\oplus^{1 \#,}$ Yuwen Cui $\oplus^{2}$, Zhuofei Liang $\oplus^{1}$, \\ Wenli Huang $\oplus^{1}$, Yi Jiang $\odot{ }^{1}$, Huawei Zhang $\oplus^{1}$ and Xiaomei Song $\odot{ }^{1 *}$ \\ ${ }^{1}$ School of Pharmacy, Shaanxi University of Chinese Medicine, Xianyang 712046, P.R. China \\ ${ }^{2}$ Department of Pharmacy, Xi'an Medical University, Xi'an 710021, P.R. China
}

(Received January 20, 2020; Revised May 29, 2020; Accepted June 03, 2020)

\begin{abstract}
A new lignan glycoside, siletatoside A (1), and three known lignans, (+)-isolariciresinol (2), balanophonin (3), and (+)-lariciresinol (4), were isolated from the roots of Silene tatarinowii Regel. Compounds 2-4 were isolated from the Silene genus for the first time. Their structures were determined based on physicochemical properties and spectroscopic methods. The structure of siletatoside A was elucidated for the first time. The cytotoxicity of $\mathbf{1 - 4}$ was evaluated in vitro in human HCT116, HT29, A549, and H1299 tumor cell lines. These compounds displayed weak cytotoxicity in the human cancer cell lines.
\end{abstract}

Keywords: Silene tatarinowii; lignan; siletatoside A; cytotoxicity. (C) 2020 ACG Publications. All rights reserved.

\section{Plant Source}

Silene tatarinowii Regel was collected in July 2018 from Shaanxi Province, China and authenticated by Prof. Jitao Wang (School of Pharmacy, Shaanxi University of Chinese Medicine, Xianyang, China). A voucher specimen (herbarium No.20180712) was stored in the Medicinal Plants Herbarium, Xianyang, China.

\section{Previous Studies}

Silene tatarinowii Regel, which belongs to the genus Silene, is used for the treatment of dropsy and rheumatism in China [1]. Characteristic components, such as ecdysteroids and triterpenoid saponins, have been isolated from plants of the Silene genus [2-3]. Ecdysteroids are present in 115 species of Silene and regarded as chemotaxonomic markers [4]. However, few phytochemical investigations on the roots of $S$. tatarinowii Regel have been reported. As part of an ongoing study on biological constituents from the roots of $S$. tatarinowii Regel, a new lignan glycoside and three known lignans, (+)-isolariciresinol (2) [5], balanophonin (3) [6], and (+)-lariciresinol (4) [7], were procured

\footnotetext{
* Corresponding authors: E-Mail: songxiaom@126.com; Phone:+86-13636733632

\#These authors contributed equally to this work
} 
(Figure 1). In this study, structure elucidaiton of the isoalted compounds and their cytotoxic activities are reported.

\section{Present Study}

The dry roots of $S$. tatarinowii Regel $(9.8 \mathrm{~kg})$ were ground into a crude powder and extracted three times with $70 \% \mathrm{EtOH}$ under reflux. After the removal of the solvent under reduced pressure, the concentrated residue was continuously fractionated with petroleum ether and $n-\mathrm{BuOH}$. The $n-\mathrm{BuOH}$ extract $(180 \mathrm{~g})$ was fractionated by column chromatography $(\mathrm{CC})$ on silica gel and eluted with $\mathrm{CHCl}_{3^{-}}$ $\mathrm{MeOH}(30: 1$ to 1:1) to produce four fractions (Fr. 1-4). A portion of Fr. 2 (26 g) with $\mathrm{MeOH}(100 \%)$ was purified over a Sephadex LH-20 column, eluted with $\left(\mathrm{CHCl}_{3}-\mathrm{MeOH}, 1: 1\right)$, and purified by HPLC (Ultimate XB- $\left.\mathrm{C}_{18}, 10 \mathrm{~mm} \times 250 \mathrm{~mm}\right)$ with $\mathrm{MeOH}-\mathrm{H}_{2} \mathrm{O}(28 \%, 3 \mathrm{~mL} / \mathrm{min})$ to produce compounds 1 (8.0 $\mathrm{mg}$ ) and $2(20.0 \mathrm{mg})$. Fr. 3 (31.8 g), using $\mathrm{MeOH}-\mathrm{H}_{2} \mathrm{O}(0: 10$ to 8:2) as the eluent, was also subjected to CC on octadecylsilyl gel to afford compounds $3(11.2 \mathrm{mg})$ and $\mathbf{4}(12.6 \mathrm{mg})$.

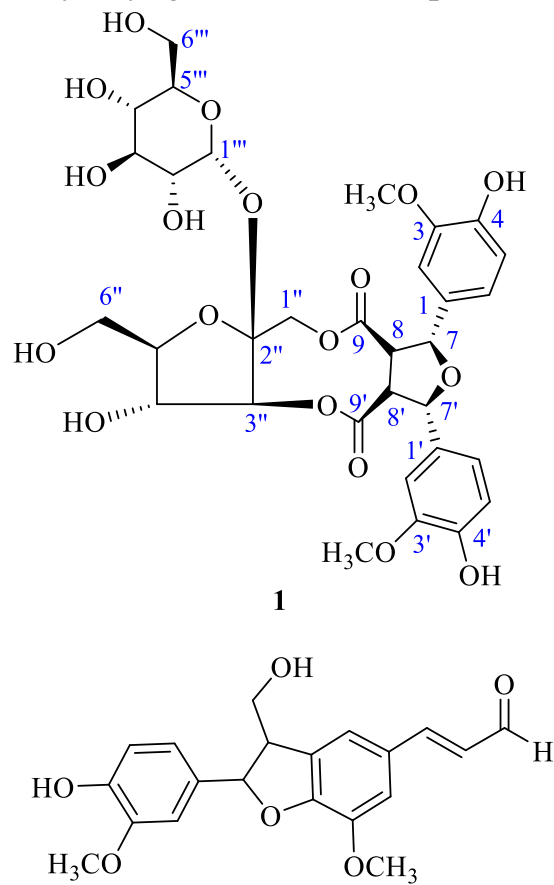<smiles>COc1cc(C2c3cc(O)c(OC)cc3CC(CO)C2CO)ccc1O</smiles>

2<smiles>COc1cc(CC2COC(c3ccc(O)c(OC)c3)C2CO)ccc1O</smiles>

4

Figure 1. Structures of compounds 1-4

Siletatoside A (1): yellow amorphous powder $(\mathrm{MeOH}) ;[\alpha]_{\mathrm{D}}{ }^{25}+37.1(c 0.01, \mathrm{MeOH})$; IR $v_{\max }$ (in $\mathrm{MeOH}) \mathrm{cm}^{-1}: 3377,2940,1735,1600,1450,1377$; UV $\lambda_{\max }(\mathrm{MeOH}): 232 \mathrm{~nm}$; HR-ESI-MS at $\mathrm{m} / \mathrm{z}$ $733.1950[\mathrm{M}+\mathrm{Na}]^{+} ;{ }^{1} \mathrm{H}-\mathrm{NMR}$ (pyridine- $\left.d_{5}, 400 \mathrm{MHz}\right): \delta_{\mathrm{H}} 7.46(1 \mathrm{H}, \mathrm{s}, \mathrm{H}-2), 7.38(1 \mathrm{H}, \mathrm{d}, J=8.2 \mathrm{~Hz}$, H-6), $7.31\left(1 \mathrm{H}, \mathrm{d}, J=8.2 \mathrm{~Hz}, \mathrm{H}-6^{\prime}\right), 7.22\left(1 \mathrm{H}, \mathrm{d}, J=7.6 \mathrm{~Hz}, \mathrm{H}-5^{\prime}\right), 7.20(1 \mathrm{H}, \mathrm{d}, J=7.6 \mathrm{~Hz}, \mathrm{H}-5), 6.18$ $\left(1 \mathrm{H}, \mathrm{d}, J=3.0 \mathrm{~Hz}, \mathrm{H}-1^{\prime \prime}\right), 5.78(1 \mathrm{H}, \mathrm{d}, J=5.2 \mathrm{~Hz}, \mathrm{H}-7), 5.72\left(1 \mathrm{H}, \mathrm{d}, J=3.7 \mathrm{~Hz}, \mathrm{H}-7^{\prime}\right), 5.53(1 \mathrm{H}, \mathrm{m}$, H-3"), $5.22(1 \mathrm{H}, \mathrm{d}, J=3.4 \mathrm{~Hz}, \mathrm{H}-5 "), 5.12(1 \mathrm{H}, \mathrm{d}, J=12.8 \mathrm{~Hz}, \mathrm{H}-1 " \alpha), 5.12(1 \mathrm{H}, \mathrm{d}, J=12.8 \mathrm{~Hz}, \mathrm{H}-$ $1 " \beta), 4.92$ (1H, m, H-2'"), 4.63 (1H, m, H-4"'), 4.63 (1H, m, H-3"'), 4.56 (1H, m, H-6'" $\alpha), 4.48$ (1H, m, H-8), 4.48 (1H, m, H-8'), 4.45 (1H, m, H-6"' $\beta), 4.28$ (1H, m, H-4"'), 4.19 (1H, m, H-5"'), 3.78 (3H, s, $\mathrm{H}-10), 3.78\left(3 \mathrm{H}, \mathrm{s}, \mathrm{H}-10{ }^{\prime}\right) ;{ }^{13} \mathrm{C}-\mathrm{NMR}$ (pyridine- $\delta_{5}, 100 \mathrm{MHz}$ ): $\delta_{\mathrm{C}} 174.6(\mathrm{C}-9), 170.7$ (C-9'), 149.3 (C3), 149.1 (C-3'), 149.1 (C-4), 148.8 (C-4'), 131.6 (C-1), 131.3 (C-1'), 121.2 (C-6), 121.1 (C-6'), 117.0 (C-5), 116.9 (C-5'), 112.4 (C-2), 111.9 (C-2'), 110.2 (C-2"), 94.9 (C-1"'), 89.1 (C-4"), 84.0 (C-7), 82.3 (C-7'), 80.5 (C-3"), 76.0 (C-3"'), 75.3 (C-2"'), 74.8 (C-5"), 74.2 (C-5"'), 72.7 (C-4"'), 65.6 (C-6"), 64.4 (C-1"), 63.7 (C-6'"), 56.8 (C-8), 56.7 (C-8'), 56.4 (C-10), 56.3 (C-10'). 
Siletatoside A (1) was a yellow amorphous powder that showed maximum UV absorption at $232 \mathrm{~nm}$. Its molecular formula was determined to be $\mathrm{C}_{32} \mathrm{H}_{38} \mathrm{O}_{18}$ based on the high-resolution electrospray ionization mass spectrometry positive ion at $\mathrm{m} / \mathrm{z} 733.1950\left[\mathrm{M}+\mathrm{Na}^{+}\right.$(calcd for $\mathrm{C}_{32} \mathrm{H}_{38} \mathrm{O}_{18} \mathrm{Na}$, 733.1956). In the ${ }^{1} \mathrm{H}$-nuclear magnetic resonance (NMR) spectrum of $\mathbf{1}$, six aromatic proton signals at $\delta_{\mathrm{H}} 7.46(\mathrm{~s}, \mathrm{H}-2), 7.20(\mathrm{~d}, J=7.6 \mathrm{~Hz}, \mathrm{H}-5), 7.38(\mathrm{~d}, J=8.2 \mathrm{~Hz}, \mathrm{H}-6)$ and $7.48(\mathrm{~s}, \mathrm{H}-$ $\left.2^{\prime}\right), 7.22\left(\mathrm{~d}, J=7.6 \mathrm{~Hz}, \mathrm{H}-5^{\prime}\right)$, and 7.31 (d, $J=8.2 \mathrm{~Hz}, \mathrm{H}-6$ ') were assigned to two ABX spin systems, along with two methoxy groups at $\delta_{\mathrm{H}} 3.78$ and 3.79 (each $3 \mathrm{H}, \mathrm{s}$ ). The anomeric proton doublet at $\delta$ 6.18 with a coupling constant $(J)$ of $3.0 \mathrm{~Hz}$ indicated that 1 was an $\alpha$-glucosyl [8]. Methine proton signals at $\delta_{\mathrm{H}} 5.72\left(\mathrm{H}^{-} 7^{\prime}\right), 5.78(\mathrm{H}-7), 4.48(\mathrm{H}-8)$, and $4.48\left(\mathrm{H}-8^{\prime}\right)$ were from the oxycyclopentane ring. The ${ }^{13} \mathrm{C}$-NMR spectrum displayed 32 carbon signals. A distortionless enhancement of polarization transfer $135^{\circ}$ experiment showed that there were eight quaternary carbons. There were two carbonyl signals at $\delta_{\mathrm{C}} 170.7$ and 174.6 in the low field region. There were two quaternary carbon signals at $\delta_{\mathrm{C}}$ (131.3 and 131.6), six methine carbon signals at $\delta_{\mathrm{C}}(112.4,111.9,116.9,117.0,121.1$, and 121.2), and four oxygenated quaternary carbon signals at $\delta_{\mathrm{C}}(148.8,149.1,149.1$, and 149.4) owing to the dual sets of $\mathrm{ABX}$ systems. Twelve oxygenated carbon signals were ascribable to two glycosyl moieties $\left(\delta_{\mathrm{C}}\right.$ 94.9, 75.3, 76.0, 72.7, 74.2, and 63.7 and $\delta_{\mathrm{C}} 64.4,110.2,80.5,89.1,74.8$, and 65.6), which indicated the existence of a glucopyranose and a fructofuranose. Four methine carbon signals at $\delta_{\mathrm{C}}(56.8,56.7$, 82.3, and 84.0) were assigned to an oxycyclopentane ring owing to the effect of electronic absorption of the oxygen atoms. Methine carbon signals C-7 and C-7' shifted to a lower field, as the C-7 and C-7' signals of the cyclobutane ring are usually perceived at $\delta_{\mathrm{C}} 44.0$ and 45.0, respectively [8]. When comparing the NMR data of 1 with a reference compound, 2,5-bis-(4-hydroxy-3-methoxyphenyl)tetrahydrofuran-3,4-dicarboxylic acid [9], the aglycone of compound $\mathbf{1}$ exhibited similar spectroscopic features, based on heteronuclear multiple quantum coherence (HMQC) and heteronuclear multiple bond coherence (HMBC).

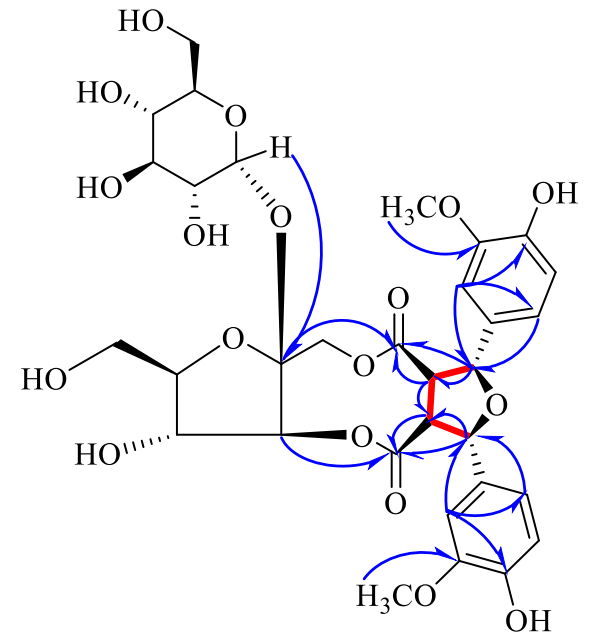

- $:{ }^{1} \mathrm{H}-{ }^{1} \mathrm{H} \mathrm{COSY}$
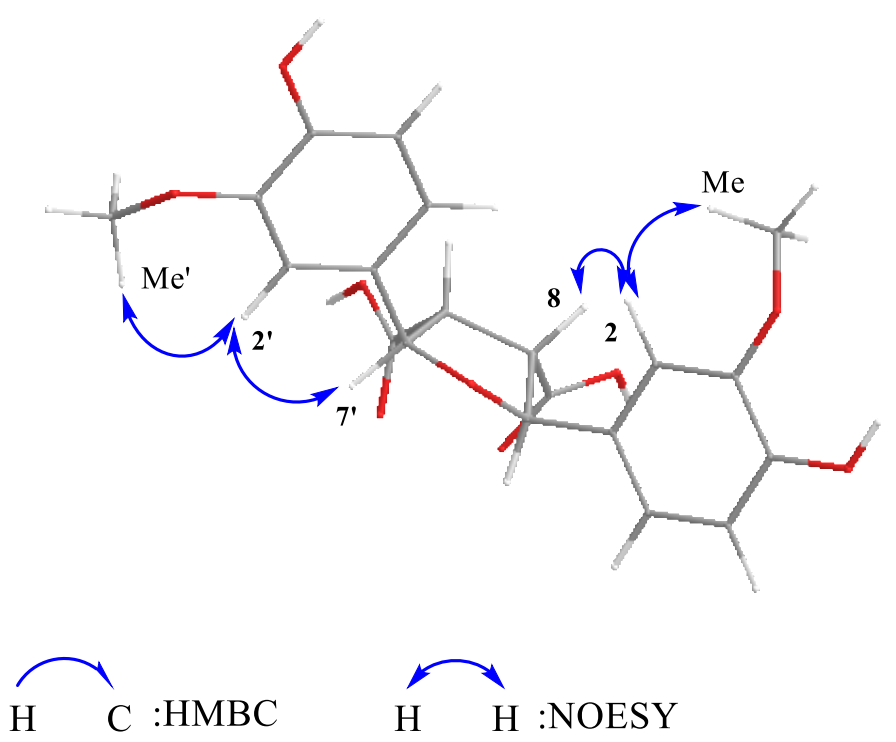

Figure 2. Key 'H - 'H COSY, HMBC and NOESY relevant of compound $\mathbf{1}$

In addition, HMBC correlations (Figure 2) of H-2/C-1, C-4, C-6, and C-7; H-2'/C-1', C-4', C6', and C-7'; H-6/C-4 and C-7; H-6'/C-4' and C-7'; H-7/C-2, C-6, C-8', and C-9; H-7'/C-2', C-6', C-8, 
and C-9'; H-8/C-8' and C-9; and H-8'/C-8 and C-9' were observed. Furthermore, the HMBC spectrum correlation signal of $\mathrm{H}-1$ "' $\left(\delta_{\mathrm{H}} 6.18\right)$ of the glucopyranosyl moiety and $\mathrm{C}-2$ " $\left(\delta_{\mathrm{C}} 110.2\right)$ of the fructofuranosyl moiety indicated that the sugar groups were connected as [ $\beta$-D-fructofuranosyl$(2 \rightarrow 1)-\alpha$-D-glucopyranose] [10]. HMBC correlations of H-1"/C-9 and H-3"/C-9' suggested that the two carbonyl carbon were attached to the fructofuranosyl moiety. Moreover, the correlations of OMe3/C-3 and OMe-3'/C-3' showed that the two methoxy groups were situated in C-3 and C-3'. In the nuclear Overhauser effect spectrum (Figure 2) of 1, the nuclear Overhauser effect correlations observed of $\mathrm{H}-2 / \mathrm{H}-8$ and $\mathrm{OMe}-3$ and $\mathrm{H}-2^{\prime} / \mathrm{H}-7^{\prime}$ and OMe-3' (Figure 2); thus, the relative configuration of 1 was determined. To determine the absolute configuration, experimental circular dichroism (CD) spectra were compared with predicted calculations from the time-dependent density functional theory, which is a quantum mechanical theory [11]. The calculated electronic $\mathrm{CD}$ spectrum for the $7 \mathrm{~S}, 8 \mathrm{R}, 7^{\prime} \mathrm{R}, 8^{\prime} \mathrm{S}-\mathbf{1}$ stereoisomer matched and the experimental $\mathrm{CD}$ data of $\mathbf{1}$ are in good agreement (Figure 3) in the proposed strcuture.

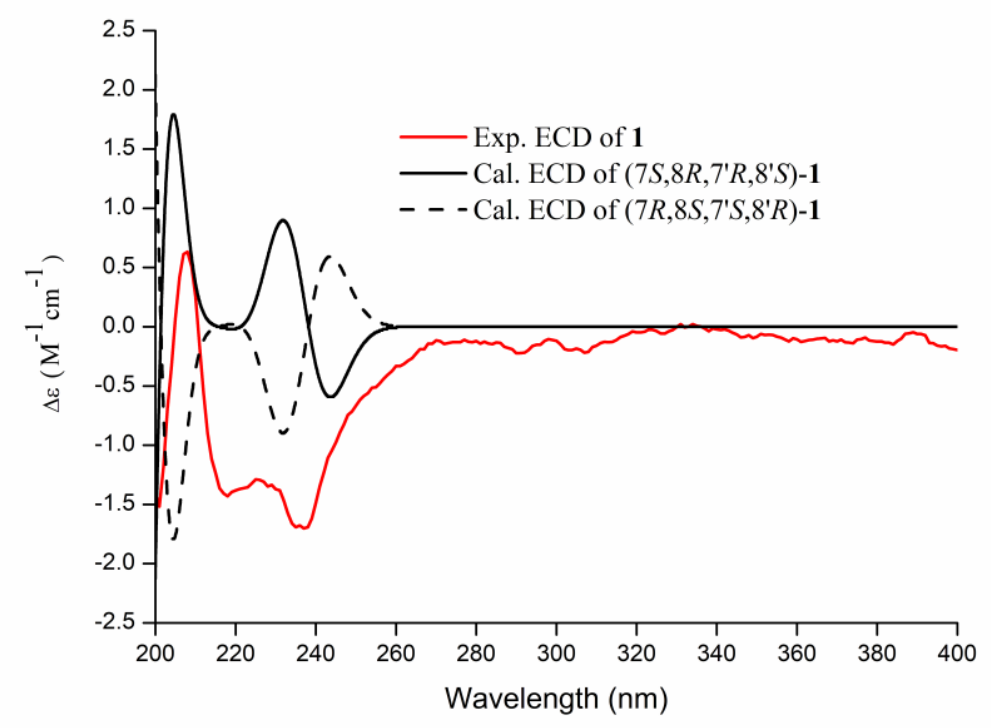

Figure 3. Experimental and calculated ECD spectra of 1 The experimental ECD spectrum of $\mathbf{1}$ (red line) and the calculated ECD spectrum of (7S,8R,7'R,8'S)-1 (black line) and (7R,8S,7'S, 8'R)-1 (black short dash)

Cytotoxicity data of compounds 1-4 against human HCT116, HT29, A549 and H1299 cell lines, the $\mathrm{IC}_{50}$ values were shown in Table 1.

$\underline{\text { Table 1. Cytotoxicity of compounds 1-4 against four human cancer cell lines in vitro }\left(\mathrm{IC}_{50}, \mu \mathrm{M}\right)^{\mathrm{a}}}$

\begin{tabular}{ccccc}
\hline Compounds & \multicolumn{4}{c}{ Cell lines } \\
\cline { 2 - 5 } & HCT116 & HT29 & A549 & H1299 \\
\hline $\mathbf{5 - F u}$ & $2.4 \pm 1.9$ & $4.3 \pm 2.1$ & $4.0 \pm 1.6$ & $3.07 \pm 0.52$ \\
$\mathbf{1}$ & $87.3 \pm 5.3$ & $99.3 \pm 2.4$ & $>100$ & $>100$ \\
$\mathbf{2}$ & $89.3 \pm 3.1$ & $>100$ & $>100$ & $>100$ \\
$\mathbf{3}$ & $69.3 \pm 3.2$ & $73.1 \pm 2.0$ & $>100$ & $>100$ \\
$\mathbf{4}$ & $>100$ & $79.6 \pm 6.8$ & $>100$ & $>100$ \\
\hline
\end{tabular}

${ }^{a}$ IC50 values are means from three independent experiments (average \pm SD) in which each compound concentration was tested in three replicate wells; ${ }^{b} 5$-fluorouracil (5-Fu) as positive control. 


\section{Acknowledgments}

This project was financially supported by Key R\&D Program of Shaanxi Province (grant No.2019ZDLSF04-03-02); Subject Innovation Team of Shaanxi University of Chinese Medicine (2019-YL12).

\section{Supporting Information}

Supporting Information accompanies this paper on http://www.acgpubs.org/journal/recordsof-natural-products

\section{ORCID}

Xiaofei Liang: $\underline{0000-0001-8018-4433}$

Yuze Li: 0000-0001-7571-3214

Yuwen Cui: 0000-0001-9153-6406

Zhuofei Liang: 0000-0003-3913-8595

Wenli Huang: 0000-0003-2767-7831

Yi Jiang: 0000-0003-1200-1441

Huawei Zhang: 0000-0003-4970-3818

Xiaomei Song: $\underline{0000-0003-1906-1578}$

\section{References}

[1] X. P. Hu (2016). Shaanxi provincial standards for medicinal materials. Shaanxi Science and Technology Publishing, Shaanxi, China,

[2] A. Simon, Z. Pongrácz, G. Tóth, M. Mák, I. Máthé and M. Báthori (2004). A new ecdysteroid with unique $9 \beta-\mathrm{OH}$ and four other ecdysteroids from Silene italica ssp. nemoralis, Steroids 69, 389-394.

[3] H. Z. Fu, K. Koike, W. Li, T. Nikaido, W. H. Lin and D. A. Guo (2005). Silenorubicosides A-D, triterpenoid saponins from Silene rubicunda, J. Nat. Prod. 68, 754-758.

[4] X. F. Liang, Y. Z. Li, H. Fan, W. L. Huang, H. W. Zhang, Y. W. Cui and X. M. Song (2019). Chemical constituents from the roots and rhizomes of Silene tatarinowii Regel, Biochem. Syst. Ecol. 86, 103932.

[5] A. K. Thomford, R. F. Ahmed Abdelhameed and K. Yamada (2018). Chemical studies on the parasitic plant Thonningia sanguinea $\mathrm{Vahl}$, RSC Adv. 8, 21002-21011.

[6] J. F. Liu, X. M. Zhang, Y. Shi, Z. Y. Jiang, Y. B.Ma and J. J. Chen (2010). Chemical constituents of the root and rhizome of Illicium henryi, Chin. J. Chin. Mater. Med. 35, 2281-2284.

[7] D. Y. Lee, M. C. Song, K. H. Yoo, M. H. Bang, I. S. Chung, S. H. Kim, D. K. Kim, B. M. Kwon, T. S. Jeong, M. H. Park and N. I. Baek (2007). Lignans from the fruits of Cornus kousa Burg. and their cytotoxic effects on human cancer cell lines, Arch .Pharm. Res. 30, 402-407.

[8] X. Liu, B. F. Zhang, L. Yang, G. X. Chou and Z. T. Wang (2014). Four new compounds from Imperata cylindrica, J. Nat. Med. 68, 295-301.

[9] P. F. Schatz, J. Ralph, F. Lu, I. A. Guzei and M. Bunzel (2006). Synthesis and identification of 2,5-bis-(4hydroxy-3-methoxyphenyl)-tetrahydrofuran-3,4-dicarboxylic acid, an unanticipated ferulate 8-8-coupling product acylating cereal plant cell walls, Org. Biomol. Chem. 4, 2801-2806.

[10] D. Y. Lee, K. M. Han, M. C. Song, D. G. Lee, Y. D. Rho and N. I. Baek (2008). A new lignan glycoside from the rhizomes of Imperata cylindrica, J. Aslan .Nat. Prod. Res. 10, 337-341.

[11] P. J. Stephens and N. Harada (2010). ECD cotton effect approximated by the gaussian curve and other methods, Chirality 22, 229-233.

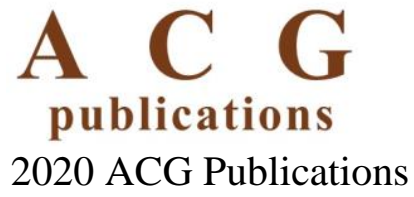

